\title{
Diatom and crustacean zooplankton communities, their seasonal variability and representation in the sediments of subarctic Lake Saanajärvi
}

\author{
Milla RAUTIO*, Sanna SORVARI and Atte KORHOLA \\ Division of Hydrobiology, Department of Ecology and Systematics, P.O. Box 17 (Arkadiankatu 7), FIN-00014 University of \\ Helsinki, Finland \\ *e-mail corresponding author: milla.rautio@helsinki.fi
}

\begin{abstract}
Present and past diatom and crustacean zooplankton communities of subarctic Lake Saanajärvi in Finnish Lapland were studied with special emphasis on their representation in the sediment surface. Two years monitoring of the present state of the lake revealed it to be ultraoligotrophic with a biomass peak during autumn overturn. Chrysophytes and diatoms were the most abundant phytoplankton groups, with four species forming the main bulk of the crustacean zooplankton community. The comparison of the present plankton community with the species composition in the sediment surface showed that only some plankton groups are suitable for paleolimnological studies. The value of diatoms for paleolimnological studies was supported by the observation that all of the species recorded from various habitats in the lake were detectable in the sediment. In addition, some species (e.g. Cyclotella glomerata) that limnological sampling had not detected were found in the sediment record. Similarly, the zooplankton class Chydoridae and Daphnia hyalina species were equally or better represented in the sediment than in the water column. On the other hand, the sediment trap and core evidence of the whole crustacean zooplankton community suggested many zooplankton species have little or no significance in paleolimnological studies. For example the two dominant copepod species, Eudiaptomus graciloides and Cyclops abyssorum, were not detectable in sediment trap samples. These findings indicate that only a small fraction of the living biota are preserved in the sediments, and this should be taken into account when drawing conclusions based on the detection of just one such species group.
\end{abstract}

Key words: diatoms, crustacean zooplankton, limnological monitoring, seasonal dynamics, taphonomy, paleolimnology

\section{INTRODUCTION}

The extreme climatic conditions of arctic and subarctic lakes modify their ecology compared with other water ecosystems (Kalff \& Welch 1974). Low temperatures slow the breakdown of dissolved chemicals in soils, terrestrial vegetation is scarce and catchments are barren and often small resulting in oligotrophic waters with low productivity and simple ecosystem structure (Capin \& Körner 1995). Low productivity and small numbers of species mean short food webs, which are usually dominated by only a few species (Hansson et al. 1993). The relatively low diversity is due to a number of factors. The severe climate with a short growing season limits the migration and expansion of many species. Environmental conditions are extreme in terms of temperature and light. Temperatures in the Arctic may range from -60 to $+35^{\circ} \mathrm{C}$. The mean July temperature, however, seldom rises above $+10^{\circ} \mathrm{C}$. Winter lasts for as much as nine months, during which the lakes are covered by ice and the sun stays below the horizon, reducing the hours of light. In addition, as a result of the last glaciation period (10-20 thousand years ago), the arctic biota is young compared with that of tropical and Antarctic ecosystems. The recent post-glacial period has not been long enough for many species to invade or to adapt to new areas and habitats in the arctic and subarctic regions (Carter et al. 1980).
The large-scale changes in the climate after the last glaciation, the sensitivity of northern waters to any environmental change and the exceptionally high number of lakes in northern Fennoscandia create challenging opportunities to undertake aquatic research from various perspectives and on various scales. Lake biota may respond to short-term seasonal changes in e.g. temperature and light regimes (Moore 1979; Sommer 1983; George \& Taylor 1995; Reynolds 1998a), possess relatively short cycles of a few years length in their lifehistory patterns or occurrences (Elmork \& Eie 1989), and reflect larger-scale environmental events in their habitats such as climate change, acidification, eutrophication and changes in the trophic states within the lake (Battarbee 1984; Charles et al. 1986; Anderson \& Renberg 1992; Douglas et al. 1994; Bennion 1995; Anderson et al. 1996, 1997; Lotter et al. 1997, 1998; Overpeck et al. 1997; Weckström et al. 1997; Sorvari \& Korhola 1998; Seppä \& Weckström 2000). As the biota are influenced by these different scales of changes simultaneously, the detection and combination of correct causes and responses are not always straightforward but require research approaches and methodologies of various types. Ecologists studying the present-day biology of lakes are seldom able to perform sampling and experiments for more than one or two seasons. The data obtained from these studies reveal a good deal of information but only on a short-term time scale. Paleolim- 


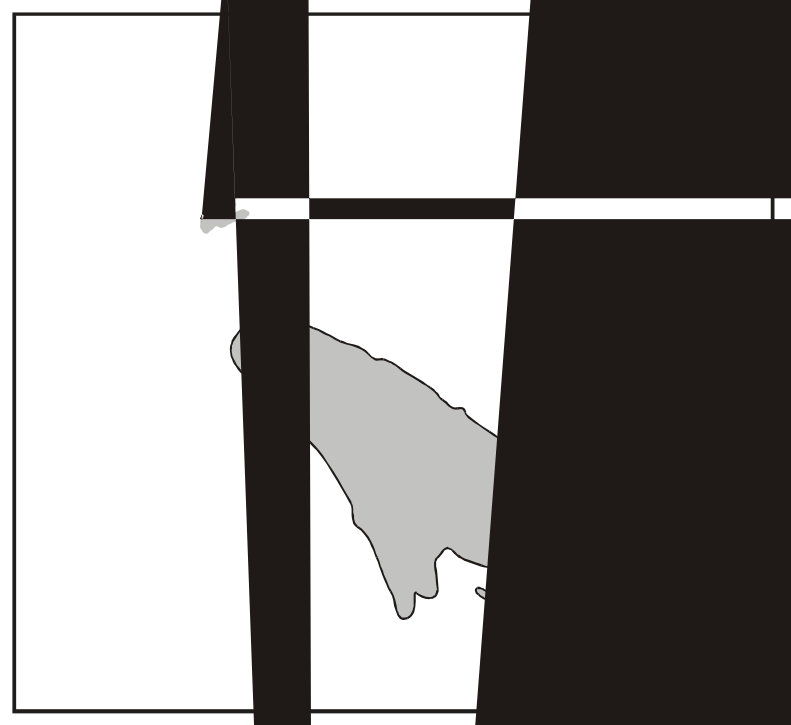

nological study, on the contrary, focuses on large-scale changes in the plant and animal communities over decades, centuries or even millenia. Despite their different perspectives, these two approaches to research can provide complementary data. The remains in the sediments and the standing crop of living biota can be correlated, as first suggested by Frey (1960). Detailed analyses of the present and past biology of lakes are numerous, but only rarely are the two used together (e.g. Haworth 1980; DeNicola 1986; Cameron 1995).

In this study we first describe the major planktonic communities and their seasonal variability in subarctic Lake Saanajärvi in Finnish Lapland and then combine the contemporary biota from two years with the sediment data from the post-industrial era. The focus is on a comparison of the species composition using different methods and from different sources such as from water column, periphyton and sediment sampling, and on the changes in plant and animal microfossil composition during the last 200 years. The taxonomic groups of concern include phytoplankton, mainly diatoms and chrysophycean stomatocysts, and crustacean zooplankton.

\section{SITE DESCRIPTION}

Lake Saanajärvi $\left(69^{\circ} 05^{\prime} \mathrm{N}, 20^{\circ} 87^{\prime} \mathrm{E}\right)$ lies at $679 \mathrm{~m}$ a.s.l. in a valley between two $\approx 1000 \mathrm{~m}$ high fells in treeless tundra, $400 \mathrm{~km}$ north of the Arctic circle and only $50 \mathrm{~km}$ away from the Arctic Ocean in the westernmost part of the Scandinavian mountain chain (Fig. 1). The area is considered one of the cleanest in Europe, with little anthropogenic pollution in the region (Rühling 1992). The lake itself is small (62 ha) and clear, with a maximum depth of $24 \mathrm{~m}$. The catchment area of 460 ha is covered by subalpine vegetation and bare rock surfaces consisting mainly of sedimentary rocks, dolomictic limestones, Paleozoic Caledonian schist and gneiss. No macrophytes occur in the lake littoral. The water column is ice-free between late June and mid-October. Lake Saanajärvi is dimictic; the maximum surface water temperature of around $15^{\circ} \mathrm{C}$ is reached in August. The nutrient content of the lake is low, the only peak in concentrations occurring at icebreak, when melting snow from the catchment brings supplementary nutrients to the lake (Sorvari et al. 2000). At the same time the $\mathrm{pH}$ value of the surface water declines temporarily from neutral to 5 as a result of the melting of acidic snow. Further characteristics of the lake are shown in table 1 and Sorvari et al. (2000).

\section{METHODS}

\subsection{Sampling of different habitats}

The pelagic water column of Lake Saanajärvi was sampled for chlorophyll- $a$, phytoplankton and zooplankton 22 times between July 16, 1996 and May 12, 1998 (Tab. 2). Chlorophyll- $a$ samples were taken from 10 depths $(0,2,4,6,8,10,12,16,20$ and $23 \mathrm{~m})$, and samples for phytoplankton were collected from 5 depths $(0,2,6,10,23 \mathrm{~m})$. All the samples were taken with a 2-1 tube-sampler, $250 \mathrm{ml}$ for phytoplankton and 3-1 for chlorophyll- $a$. On the boat, chlorophyll- $a$ bottles were kept in a black plastic bag to avoid post-sampling photosynthesis and brought into a hut at the lakeshore for filtering. Samples were filtered using Whatman GF/F filters, which were then wrapped into a foil and placed in a freezer after returning to a laboratory. Within 6 months from the time of sampling chlorophyll- $a$ contents were measured with a spectrophotometer using a 96\% ethanol extraction method. Phytoplankton samples were preserved in a Lugol's iodine in the field and later counted with an inverted microscope. The phytoplankton counting units were cells, colonies and trichomes with a length of $100 \mu \mathrm{m}$. The pelagic zooplankton samples were taken integrally using a net with $200 \mu \mathrm{m}$ mesh 
Tab. 1. Minimum, maximum, mean and median values of physical, chemical and biological data for Lake Saanajärvi during the sampling period 1996-1998 (4 June 1996 - 13 May 1998).

\begin{tabular}{|c|c|c|c|c|}
\hline Parameter & Min. & Max. & Mean & Median \\
\hline Temperature & 0.2 & 14.6 & 4.8 & 4.5 \\
\hline $\mathrm{pH}$ & 5.4 & 7.9 & 6.9 & 6.9 \\
\hline Conductivity $\left(\mu \mathrm{S} \mathrm{cm}^{-1}\right)$ & 8.5 & 62.0 & 27.4 & 27.1 \\
\hline Alkalinity $\left(\mu\right.$ eq $\left.1^{-1}\right)$ & 141.1 & 210.7 & 162.1 & 157.3 \\
\hline Tot. $\mathrm{P}\left(\mu \mathrm{g} \mathrm{l}^{-1}\right)$ & 0.0 & 10.5 & 2.7 & 2.9 \\
\hline Tot. $N\left(\mu g 1^{-1}\right)$ & 99.0 & 157.0 & 124.8 & 123.0 \\
\hline $\mathrm{NH}_{4}-\mathrm{N}\left(\mu \mathrm{g}^{-1}\right)$ & 0.0 & 68.9 & 9.7 & 9.2 \\
\hline $\mathrm{NO}_{3}-\mathrm{N}\left(\mu \mathrm{g}^{-1}\right)$ & 3.5 & 383.5 & 40.5 & 30.4 \\
\hline $\mathrm{Ca}\left(\mathrm{mg} \mathrm{l}^{-1}\right)$ & 0.5 & 5.0 & 3.0 & 3.0 \\
\hline $\operatorname{Mg}\left(\mathrm{mg} \mathrm{l}^{-1}\right)$ & 0.1 & 1.1 & 0.7 & 0.7 \\
\hline $\mathrm{Na}\left(\mathrm{mg} \mathrm{l}^{-1}\right)$ & 0.5 & 3.0 & 1.2 & 0.2 \\
\hline $\mathrm{K}\left(\mathrm{mg} \mathrm{l}^{-1}\right)$ & 0.1 & 0.5 & 0.2 & 0.2 \\
\hline $\mathrm{SO}_{4}\left(\mathrm{mg} \mathrm{l}^{-1}\right)$ & 0.8 & 7.2 & 4.1 & 4.2 \\
\hline $\mathrm{Cl}\left(\mathrm{mg} \mathrm{l}^{-1}\right)$ & 0.6 & 6.4 & 1.7 & 1.7 \\
\hline Chlorophyll- $a\left(\mu \mathrm{g} \mathrm{l}^{-1}\right)$ & 0.0 & 1.7 & 0.6 & 0.3 \\
\hline
\end{tabular}

Tab. 2. The sampling schedule of Lake Saanajärvi between 4 June 1996 -13 May 1998.

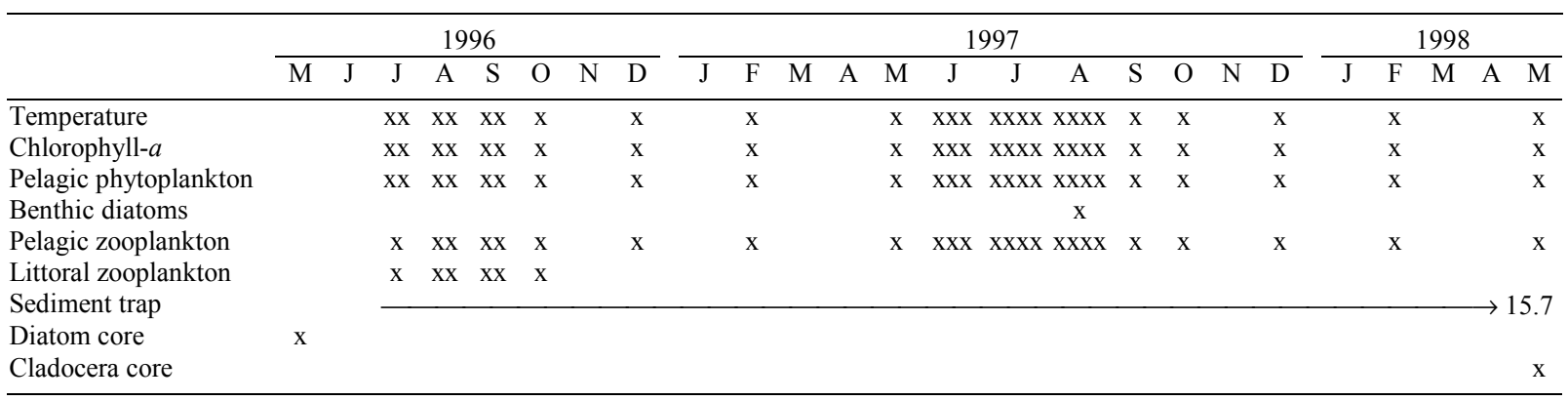

size. The net was lowered to the bottom of the lake and slowly pulled back to the surface, where its contents were emptied into a bottle. Each sample was preserved with formaldehyde, and the final concentration was about $4 \%$; and later counted under a binocular microscope for identification at the species level.

Littoral zooplankton was collected close to the shore by pulling a plankton net with $100 \mu \mathrm{m}$ mesh size for several meters just above the rocky bottom. The sample collected was preserved in the same way as the pelagic sample.

The benthic diatom habitats were sampled to examine the variability of diatom communities in the lake. 12 samples were collected in August 1997 from the lightest side of the lake along the transect extending from the shore to the deepest point of the lake. The first 8 samples were removed from stones by toothbrush and distilled water, and the rest of the samples (4) were taken from sediment surface. Sampling was performed by diving and by a Glew corer. Samples were concentrated in the laboratory from $200 \mathrm{ml}$ to approx. $10 \mathrm{ml}$, and Lugol's iodene was removed by 5-step centrifugation dilution. After centrifugation, samples were treated with $\mathrm{H}_{2} \mathrm{O}_{2}$ and $\mathrm{HCl}$. Slides were mounted on objective glass using Naphrax as a mounting medium.

\subsection{Sediment traps}

The material in sediment traps was used to describe the seasonal succession of diatoms and chrysophyte cysts in the lake as well to clarify the pathways of sedimentation for the studied organisms, including cladocerans. Two parallel cylindrical sediment traps were placed in the lake at the beginning of July at the deepest point of the lake at a depth of $23 \mathrm{~m}$, i.e. one meter above the sediment surface. Accumulated material was emptied monthly during the open-water season, and after the autumn overturn traps were left exposed for the icecover period. Altogether 7 trap samples for diatoms, chrysophyte cysts and cladocerans were investigated during the study period. At the time of collection, samples were preserved with Lugol's Iodene and divided in smaller proportions in the laboratory.

Diatom and chrysophyte cyst samples were concentrated from $500-1000 \mathrm{ml}$ to $10 \mathrm{ml}$ and Lugol's iodine was washed away. Diatom and cyst trap samples were treated using the same procedure as for diatom transect samples. Microspheres were added in the samples to estimate total diatom and cyst concentrations. Total cyst concentrations were counted together with diatom counts. Because the samples represent different tempo- 
ral scales, concentrations are expressed as number of valves day ${ }^{-1} \mathrm{l}^{-1}$ in order to enable comparison.

We calculated the proportion of diatom frustules to chrysophyte cysts (D:C) for trap samples in order to compare roughly the seasonal variability of these two algal groups. This ratio is believed to provide valuable information about the relative abundance of these two algal groups, and to reflect changes in nutrient state and growing season (Smol 1985; Douglas \& Smol 1995). Diatom - chrysophyte cyst ratio was calculated from formula $\mathrm{D}: \mathrm{C}=$ (number of diatom frustules/number of chrysophyte cysts + number of diatom frustules $) \times 100$.

Zooplankton samples of $500 \mathrm{ml}$ were counted by the Utermöhl technique (Utermöhl 1958) using an inverted microscope. Species composition is expressed as a percentage of the total zooplankton abundance counted in each sample.

\subsection{Sediment core: sampling and analyses}

Sediment material for the analysis of subfossil diatom valves, chrysophyte cysts and cladoceran remains was collected from the ice at the deepest point $(24 \mathrm{~m})$ of the lake with a $5 \mathrm{~cm}$ diameter Glew corer. A $20 \mathrm{~cm}$ long core coded SAAN3 was taken for diatoms and chrysophytes in May 1996, extruded immediately in the field at $2 \mathrm{~mm}$ intervals and stored in small plastic bags. Samples were stored at $4{ }^{\circ} \mathrm{C}$. Core SAAN5 $(15 \mathrm{~cm})$ for cladocera was taken in May 1998 and extruded at $5 \mathrm{~mm}$ intervals in laboratory within $2 \mathrm{~h}$ of sampling. During extrusion sediment was subsampled into two fractions and $2 \mathrm{~cm}^{3}$ of wet sediment was stored in plastic tubes at $4{ }^{\circ} \mathrm{C}$ for cladoceran analysis, while the rest of the sediment was placed in Eppendorf tubes and dried immediately for dry weight and loss-on-ignition analysis. The cores were dated by correlation with the lead-210 dated master core (SAAN4). Both sediment percentage dry weight and loss-on-ignition profiles were then related to the master core using the sequence slotting method developed by Thompson \& Clark (1993). For a more detailed description of sediment dating and core correlation methods, see Korhola et al. (1999).

$0.2 \mathrm{~g}$ of wet sediment was used for diatom and chrysophyte cyst analyses. Samples were treated with $\mathrm{H}_{2} \mathrm{O}_{2}$ and $\mathrm{HCl}$. Cleaned diatoms, cysts and microspheres were mounted on microscope slides with Naphrax. Diatom slides were counted using Olympus BX40 with $\times 1000$ magnification, using phase contrast and an oil immersion lens. A minimum of 500 diatom valves was counted per sample. Simultaneously with diatom counts the total number of chrysophyte cysts was determined. Standard floras were mainly used in the diatom identification. In addition, for arctic Achnanthes sp. I unpublished notes of the Arctic-Antarctic Diatom Workshop held in Quebec, Canada (Laing 1997) were used and for the description of Aulacoseira italica subsp. subarctica type II, see Sorvari \& Korhola (1998).
Stored sediment for the Cladocera analysis was mixed with $150 \mathrm{ml}$ of $10 \% \mathrm{KOH}$ and heated to approximately $80{ }^{\circ} \mathrm{C}$, stirring continuously with a magnetic stirrer. After half an hour the $\mathrm{KOH}$-sediment mixture was poured onto a $50 \mu \mathrm{m}$ sieve and washed under running water. The sediment remaining in the sieve was carefully diluted to a volume of $10 \mathrm{ml}$, and 2-3 drops of safranin-glycerin solution were added to color the cladoceran remains in the sample. Prior to microscopy, the tube was carefully shaken so that the contents were homogenized and 2 slides were prepared by pipetting $200 \mu \mathrm{l}$ of the sample onto an object glass, which was then covered with a $24 \times 50 \mathrm{~mm}$ cover slip and counted at magnifications $\times 120-240$. All cladoceran body parts found were counted, but only the most frequent for each taxon was used as an index of the species abundance. The following sources were used in the identification: Frey $(1959,1960)$ and Flössner (1972).

\subsection{Data analyses}

The diatom transect data was subjected to multivariate data analysis. Detrended correspondence analysis (DCA; Hill \& Gauch 1980) was used first to determine whether linear- or unimodal-based numerical techniques were more appropriate for the data (ter Braak \& Prentice 1988). This analysis yielded a gradient length of 1.44 standard deviations (S.D.) for the first DCA axis, suggesting that the diatoms are responding linearly along the major ecological gradient. Thus, PCA with centering and standardization was performed for squareroot-transformed transect diatom data. Square-root transformation was used in order to optimize the signalto-noise-ratio in the data and to stabilize the variances (Prentice 1980). Unfortunately, the data had a mathematical artefact, arch effect (Hill \& Gauch 1980), and therefore DCA with detrending by segments, non-linear rescaling of axes and downweighting the rare species was used for the diatom transect data set. PCA and DCA were performed using the FORTRAN program CANOCO, version 3.10 (ter Braak 1988, 1990).

Floristic similarity between planktonic diatom assemblages, determined from the trap and the sediment core material, and periphytic diatom assemblages, determined from the transect and the sediment core material, was analysed using the squared Chi-square distance method described in Flower et al. (1997). The method uses weighted diatom proportions to determine the difference between assemblages (Overpeck et al. 1985). Diatom proportions are presented as percentiles, and therefore the calculated values of squared Chi-square distance vary from zero to two, with zero indicating an identical assemblage. When analyzing the transect data, deep-water sediment samples (21 to $24 \mathrm{~m}$ ) were removed from the analysis because they originate from the same area of accumulation in the lake basin as do the sediment core samples. 


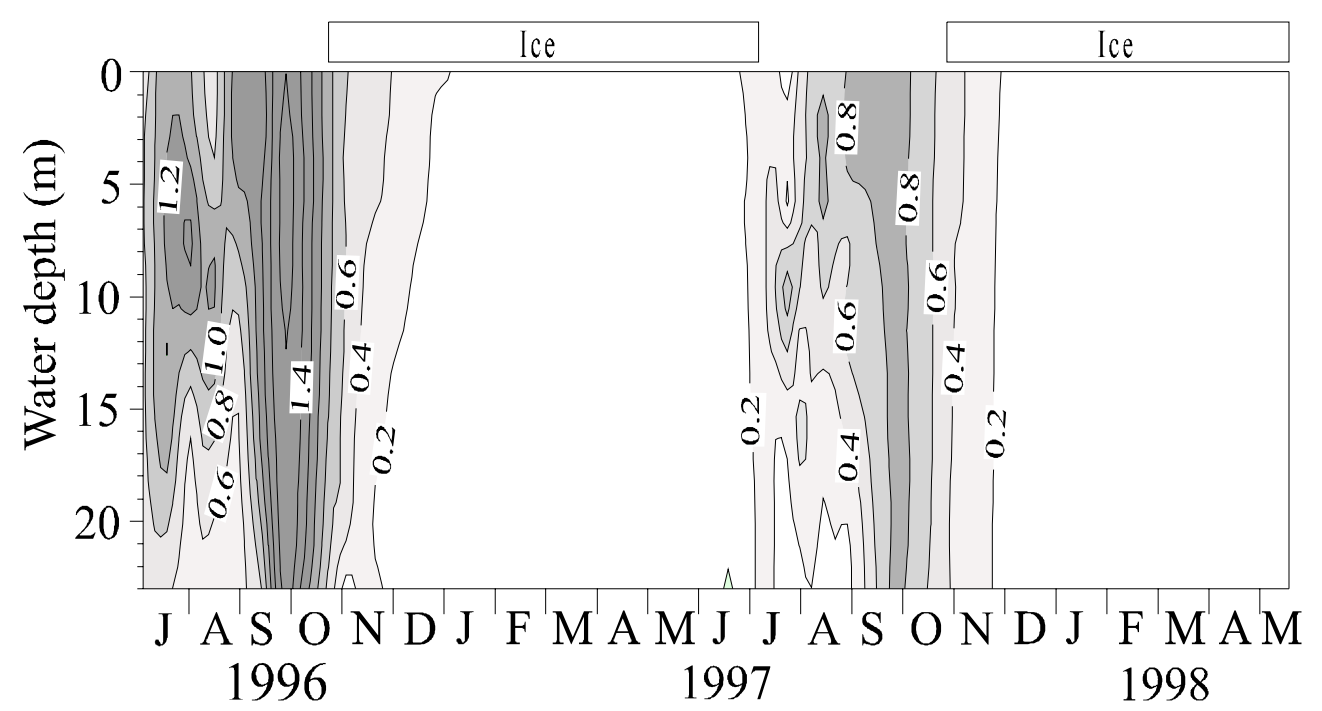

Fig. 2. The chlorophyll- $a\left(\mu \mathrm{g} \mathrm{l}^{-1}\right)$ contents of the lake.

\section{RESULTS AND DISCUSSION}

\subsection{Seasonal variability of phytoplankton}

Lake Saanajärvi can be considered to be an ultraoligotrophic lake as a result of its low phytoplankton biomass and densities (range 5700 - 220,000 counting units $100 \mathrm{ml}^{-1}$ ) (Forsström 2000). The maximum biomass in both monitoring years occurred at the time of the autumn overturn in September with chlorophyll- $a$ ranging between 1.0-1.5 $\mathrm{Mg}^{-1}$ (Fig. 2). During thermal stratification the thermocline formed a gradient of chlorophyll- $a$ concentrations between the epilimnion with the higher biomass at around $1 \mu \mathrm{g} \mathrm{l}^{-1}$, and the hypolimniom with lower biomass at around $0.3 \mu \mathrm{g} \mathrm{l}^{-1}$. In the dark polar winter between November and February chlorophyll- $a$ concentrations declined to close to zero in the entire water column.

Chrysophytes were the most abundant group throughout the year except for early spring and midwinter. In August 1997 they contributed over 90\% of the phytoplankton density and in most samples they made over $50 \%$ of phytoplankton (Forsström 2000). Diatoms with contributions from $0-62 \%$ of the total phytoplankton density were the second most abundant group in the lake. The seasonal succession of most phytoplankton had a similar pattern in both years.

Seasonal variability of diatoms was studied more carefully because they are important bioindicators that are often studied from the sediment. Fossil preservation of diatoms is generally good, and information about the past communities can be obtained directly from morphological remains (Anderson \& Battarbee 1992). Sediment trap samples were used as a measure of diatom succession. Cameron (1995) has shown that seasonal variability of diatoms can be recorded in a sediment trap accurately and without apparent delay.
Moreover, trap samples capture seasonal changes as a continuum, with a larger spatial and temporal coverage than the plankton samples taken from a water column once a week. However, post-depositional resuspension has to be taken into account when interpreting the trap data.

Cyclotella comensis, C. rossii, C. glomerata, Thalassiosira pseudonana and Aulacoseira subarctica were the most dominant planktonic diatoms in the sediment trap samples (Fig. 3). Although these taxa were present in high numbers in 1996, they were almost absent during the open-water period in 1997. This inter-annual variability is most probably as a result of competition with phytoplankton. In 1997, chrysophyte species dominated the water column composing over $90 \%$ of the total phytoplankton density and suggesting more favourable conditions for chrysophytes (unpublished). Cyclotella comensis was the dominant diatom species (maximum accumulation rate 180,000 valves day ${ }^{-1} 1^{-1}$ ) early in the autumn overturn 1996, when the thermal stratification broke down and available nutrients were released to the whole water column from the hypolimnion. Phytoplankton, including planktonic diatoms, benefit from these nutrient rich conditions with increased turbulence in the water column (Gaedke et al. 1998). Thalassiosira pseudonana had its maximum production $\left(13,000\right.$ valves day $\left.{ }^{-1} 1^{-1}\right)$ in August 1996 at the same time as $C$. comensis. A peak of Cyclotella rossii (maximum 81,000 valves day $^{-1} 1^{-1}$ ) accumulation during the late autumn overturn followed blooms of $C$. comensis and T. pseudonana in 1996. C. glomerata had low accumulation rates (varying from 0 to 8000 valves day ${ }^{-1}$ $\mathrm{l}^{-1}$ ) throughout the study period although it is one of the dominant diatom taxa in the sediment of Lake Saanajärvi. These low rates of accumulation are probably the result of resuspension, and therefore C. glomerata did not necessarily inhabit the water column during the 


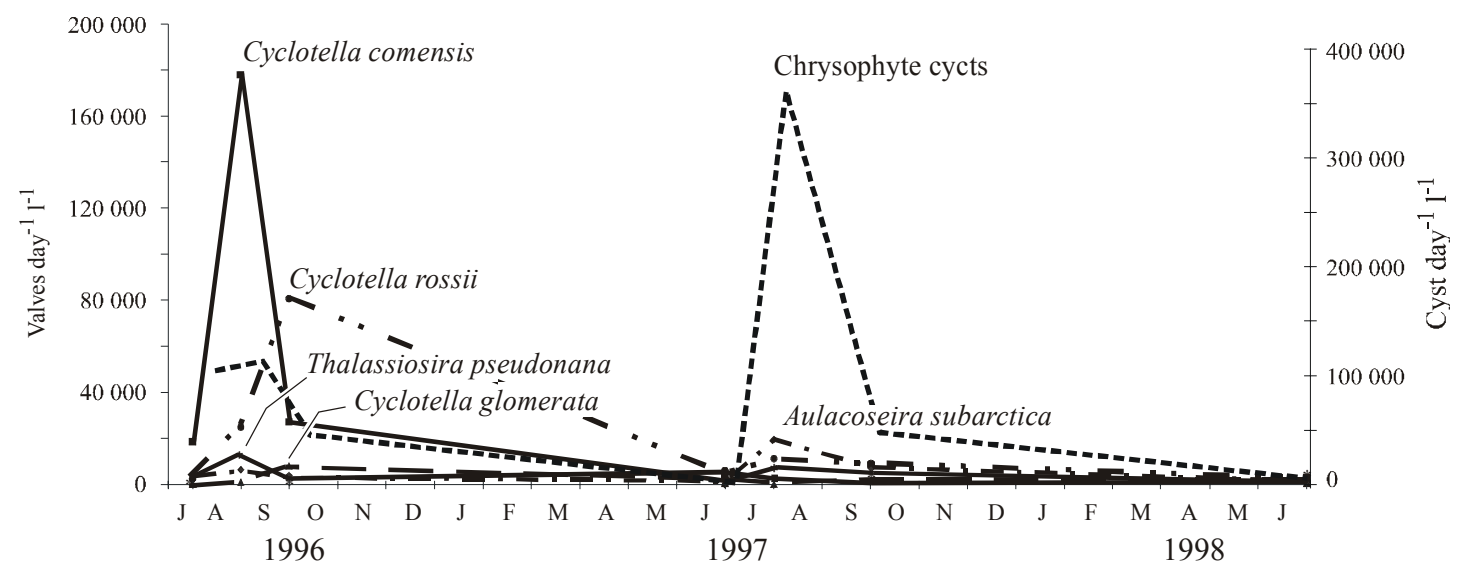

Fig. 3. The five most abundant diatom taxa and total chrysophyte cyst concentrations in the trap samples. Concentrations are expressed valves per day for diatoms and cycts per day for chrysophytes in one liter volume.

study period. Plankton studies from Lake Saanajärvi support this conclusion, as only a few cells of $C$. glomerata were found in plankton samples in 19961997 (unpublished). Unfortunately, little is known about the ecology of C. glomerata. Reynolds (1998b) classifies $C$. glomerata as a taxon related to ultraoligotrophic, clear-water lakes, and Kalff et al. (1975) found that $C$. glomerata dominated the plankton in Meretta Lake in Arctic Canada during the period of declining light in October, which may indicate that $C$. glomerata blooms late in autumn overturn or under the ice. In Swedish lake sediment studies, Anderson et al. (1997) found $C$. glomerata to be subdominant with $C$. kuetzingiana (=includes $C$. rossii as well as other Cyclotella taxa), which is also the case in the sediment of Lake Saanajärvi. Anderson et al. (1997) plotted the abundance of $C$. glomerata against different water chemistry parameters in a set of Swedish lakes used to investigate the ecology of the taxon. According to their observations, $C$. glomerata is found today in lakes with $\mathrm{pH}$ higher than 6.5 and low nutrient concentrations (TP under $10 \mu \mathrm{g} \mathrm{l}^{-1}$ and $\mathrm{NO}_{3}-\mathrm{N}$ under $100 \mu \mathrm{g} \mathrm{l}^{-1}$ ). This corresponds very well with the limnological conditions of Lake Saanajärvi. However, more monitoring is required for a comprehensive understanding of the seasonal variability of C. glomerata.

Aulacoseira subarctica was the most abundant diatom taxon in the water column in July 1997, with a maximum of 19,000 valves day ${ }^{-1} 1^{-1}$. Generally, Aulacoseira species inhabit the water column in early spring during the overturn, when the turbulence of the water is sufficient to keep the species in the euphotic zone. Turbulent conditions are especially important for Aulacoseira subarctica because of its rapid sinking rate resulting from a high silica content (Round et al. 1990). It may be due to this characteristic that Aulacoseira subarctica had its maximum abundance during the brief spring overturn in 1997.

Total chrysophyte cyst numbers varied from 5,000 to $34 \times 10^{4}$ cysts day ${ }^{-1} 1^{-1}$, the highest values being ob- served in July 1997 (Fig. 3). Chrysophyte cysts may be produced by either asexual or sexual reproduction, but they are believed to be morphologically identical in both cases (Cronberg 1986; Duff et al. 1995). Unfortunately, little is known about the encystment process, but it is suggested that sexual formation is more density-dependent than related to other environmental stresses (Duff et al. 1995). Although much ecological information is lost when lumping all cyst morphotypes together, the diatom frustule and total chrysophyte cyst ratio is used succesfully in paleolimnological investigations (e.g., Smol 1985; Zeeb \& Smol 1993; Facher \& Schmidt 1996; Lotter et al. 1997, 1998; Wilkinson et al. 1999). The results clearly show that early summer samples had lower ratios (in 199629.9 and in 1997 11.1) than the autumn and winter samples, indicating that during the early summer chysophytes were more common in the water column than diatoms. In contrast, the autumn and winter samples were dominated by diatoms, with D:C being 69.8 for September 1996 and 70.0 for winter 1996/1997. In 1997, autumn and winter D:C ratios were generally lower than in 1996.

\subsection{Diatoms from the transect}

A total of 132 diatom taxa belonging to 25 genera were enumerated from benthic samples (Fig. 4). Achnanthes minutissima, Brachysira vitrea and Denticula tenuis along with Cocconeis placentula, and various Achnanthes, Cymbella and Gomphonema species dominated the first 7 epilithon samples from the shore. The shift from the epilithic communities to the sediment-associated and planktonic communities was clear; planktonic species like Cyclotella comensis, C. glomerata, $C$. rossii and Thalassiosira pseudonana increased markedly in proportions when moving from rock surfaces to sediments. Also certain benthic species, such as Fragilaria brevistriata, F. pseudoconstruens, Navicula minima v. minima and Navicula schmassmannii, occurred in high numbers in surface sediment samples. DCA was used to investigate the principle patterns of floristic 


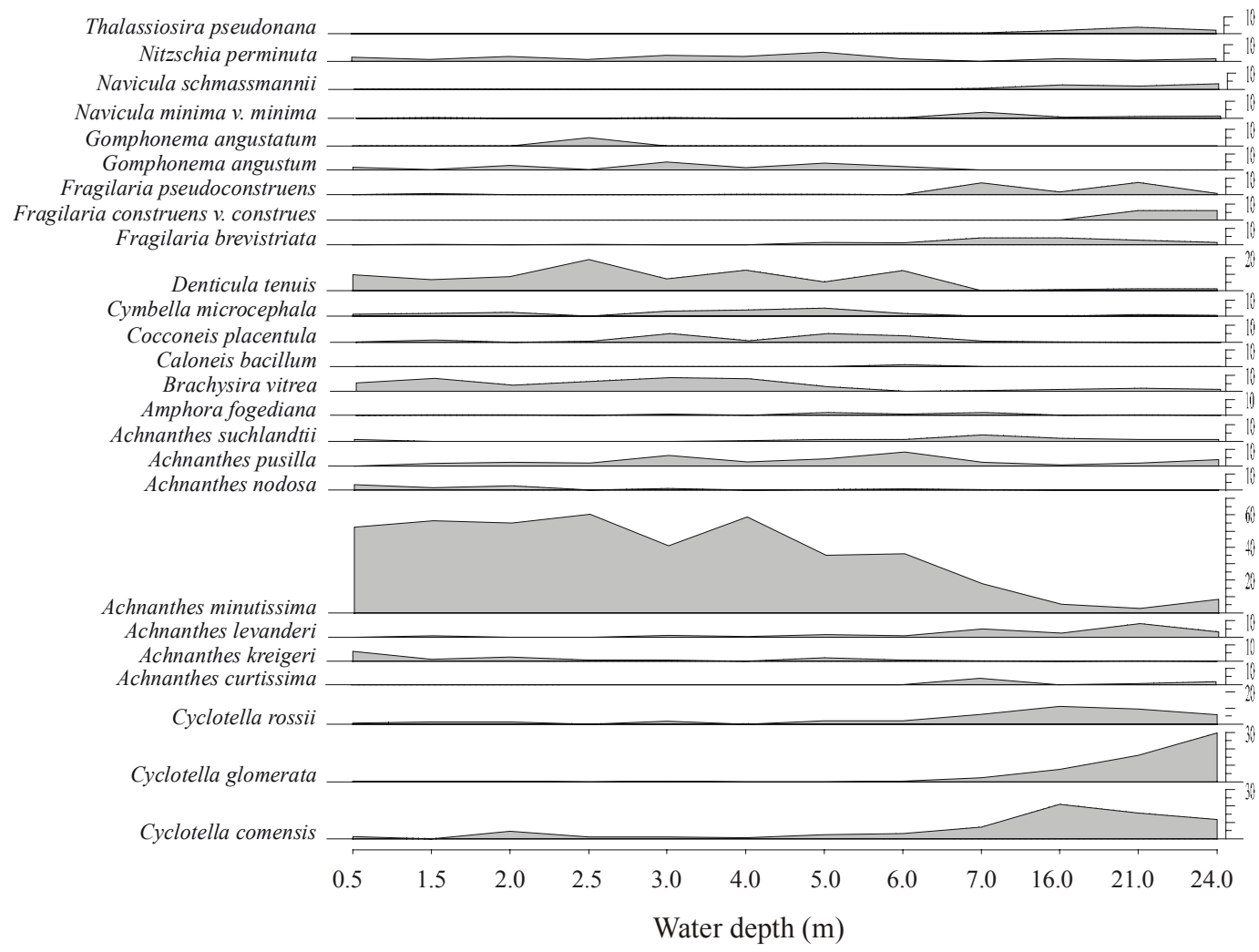

Fig. 4. The most dominant diatom taxa (species $>3 \%$ occurrence) from the transect samples. Note the changes in the water depth scale.

variation in our data. Altogether relative proportions of 132 taxa from 12 samples were used in the data analysis. Despite a large number of taxa and many zero values the first two axes captured $40.8 \%$ of total variance in the diatom data (1. axis $31.4 \%$ and 2 . axis $9.4 \%$ ). It seems that the first axis was mainly a habitat axis (Fig. 5). DCA classified transect samples into three clear groups, where the first group was characterized by epilithic samples, the second group was formed from sediment samples taken from $7 \mathrm{~m}$ to $16 \mathrm{~m}$ water depth and the third group consisted of sediment samples taken close to the deepest point of the lake (21 to $24 \mathrm{~m}$ ).

\subsection{Diatom sediment records}

The sediment core $(20 \mathrm{~cm})$ taken from the deepest point of Lake Saanajärvi contains well-preserved diatom frustules and chrysophyte cysts. The number of diatoms and chrysophyte cysts was relatively high throughout the core, varying from $45 \times 10^{6}$ to $410 \times 10^{6}$ valves $\mathrm{cm}^{-3}$ and from $8.4 \times 10^{6}$ to $84 \times 10^{6}$ cyst $\mathrm{cm}^{-3}$, respectively. Altogether 201 diatom taxa belonging to 30 genera were identified from the sediment core samples. This relatively high number of species is typical of oligotrophic subarctic lakes in northern Lapland. For example, Weckström et al. (1997) recorded 338 diatom taxa from surface sediment samples taken from 37 lakes in northwestern Finnish Lapland. Concentrations of common taxa in the stratigraphy are presented in figure 6.

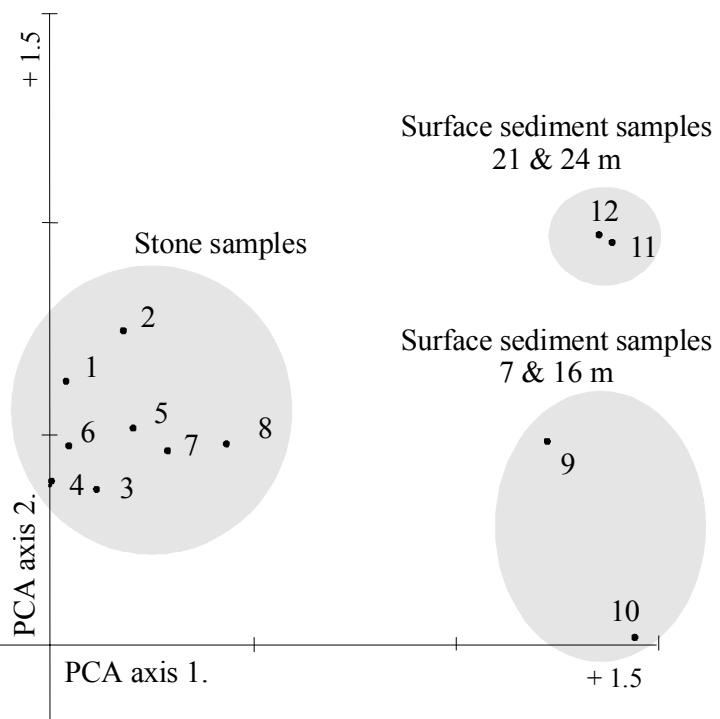

Fig. 5. The distribution of the transect diatom samples in the DCA ordination diagram.

The diatom assemblages are characterized by planktonic Cyclotella species, such as Cyclotella comensis, $C$. glomerata, C. rossii, C. schumannii, Thalassiosira 


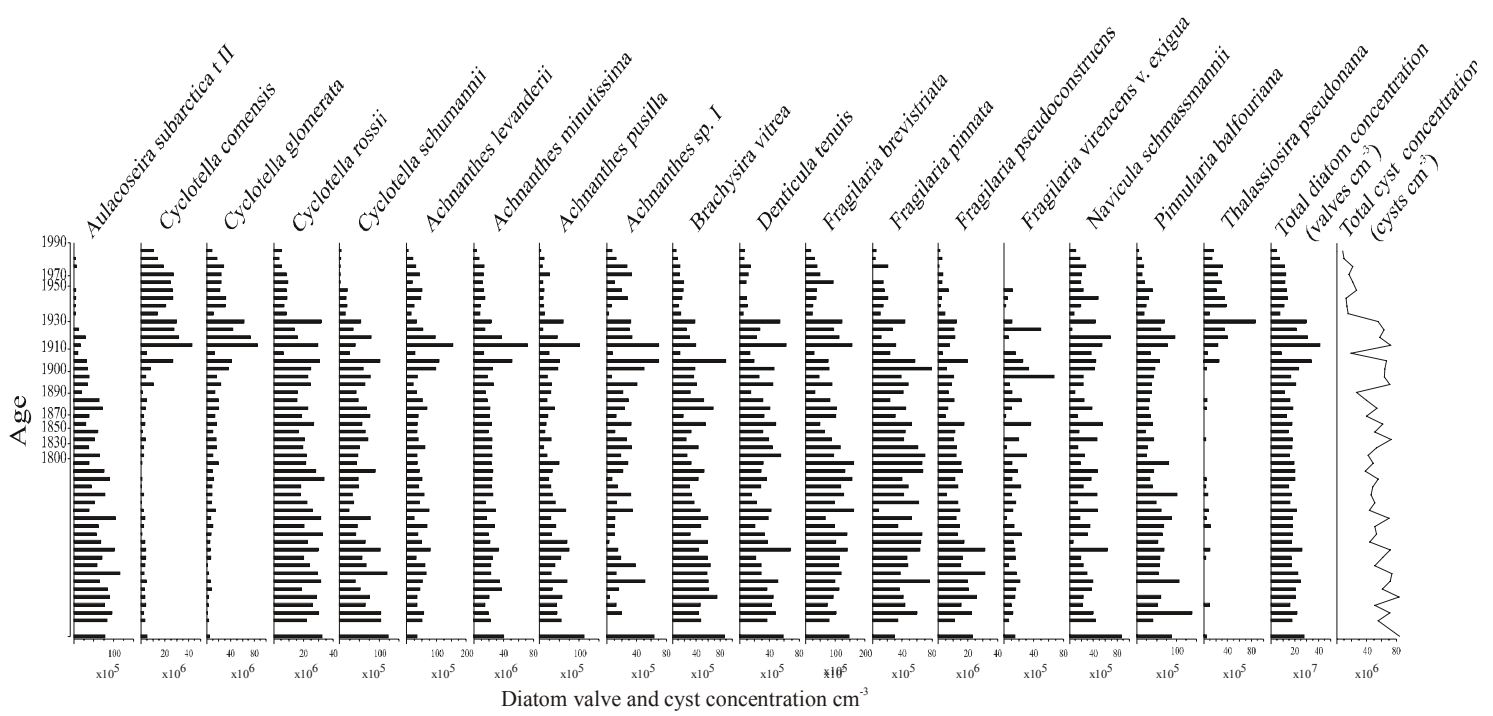

Fig. 6. Concentration of the dominant diatom taxa ( $>3 \%$ in abundance in any samples) in the sediment of Lake Saanajärvi. Note that the concentration scales vary between taxa.

pseudonana and tychoplanktonic Aulacoseira subarctica type II being the most common species. The most abundant benthic species in the stratigraphy were epilithic A. minutissima, Achnanthes levanderi, $A$. pusilla, Brachysira vitrea and attached benthic Fragilaria, Navicula and Pinnularia species, such as F. pseudoconstruens, F. brevistriata, N. schmassmannii, and $P$. balfouriana.

Towards the sediment surface the concentrations of all benthic species decline and planktonic species increase, suggesting a shift from benthic dominated communities to dominance of plankton community in the beginning of the $20^{\text {th }}$ century. This floristic change is clearly manifested by multivariate analysis of the core diatom data [detrended correspondence analysis see Sorvari \& Korhola (1998), and principal component analysis, see Korhola et al. (2000)]. The observed change in diatom assemblages is accompanied by several other parallel changes in independent proxies also studied from Lake Saanajärvi. Lake sediment, tree-ring, glacier and marine sediment studies from high-latitude regions (Douglas et al. 1994; Gajewski et al. 1997; Overpeck et al. 1997; Jones et al. 1998; Moberg \& Alexandersson 1997) suggest pronounced warming starting from the mid- $19^{\text {th }}$ century and peaking in the 1930 's. Site-specific monthly air temperature reconstruction based on European-wide, long-term meteorological data show a similar trend in Lake Saanajärvi. All the bioindicators studied showed a marked correlation to the reconstructed mean annual air temperature (Korhola et al. 2000). We postulate that post- Little Ice Age warming affected surface water temperatures in Lake Saanajärvi. With warmer surface water and stronger thermal stability environmental conditions have become more suitable for phyto- and zooplankton growth and have changed the overall primary production from benthos to plank- ton. For a more comprehensive description of the history of Lake Saanajärvi, see Korhola et al. (2000).

\subsection{Seasonal variability of zooplankton}

During the observation period 4 species; Eudiaptomus graciloides, Daphnia hyalina, Cyclops abyssorum and Holopedium gibberum dominated the crustacean zooplankton fauna in the pelagic zone of the lake. These species, excluding C. abyssorum, have been repeatedly reported from northern Scandinavian mountain lakes (e.g. Nauwerck 1994, Selin \& Hakkari 1982). The dominant Cyclopoida species is usually Cyclops scutifer (Nauwerck 1994), but according to Rylov (1963) $C$. abyssorum also frequently occurs in the region. In Lake Saanajärvi, the most abundant species was E. graciloides with a clear annual maximum of up to 900 individuals $\mathrm{m}^{-3}$ in winter during both monitoring years (Fig. 7). The summer abundance of E. graciloides varied between less than 50 individuals $\mathrm{m}^{-3}$ in late July in 1996 over 500 individuals $\mathrm{m}^{-3}$ in early July in 1997. The summer minimum is mainly due to the life-history of $E$. graciloides which reproducers in late winter and had the nauplius phase during early summer. Thus, the summer minimum is clearly a result of the use of a $200 \mu \mathrm{m}$ plankton net, which does not catch small-sized naupliar stages. There was no clear variability in seasonal density in the abundance of Cyclops abyssorum, which is most probably related to the life cycle of the species, which lasts for more than one year. According to Elgmork \& Eie (1989) the life cycle of Cyclops scutifer in high mountain lakes was prolonged to a three-year cycle in lakes with long periods of winter stagnation and low water temperatures. As a species from the same genus, $C$. abyssorum probably responds to the environment in the same way. In summer 1996 C. abyssorum was quite abundant, over 300 individuals $\mathrm{m}^{-3}$, after that 


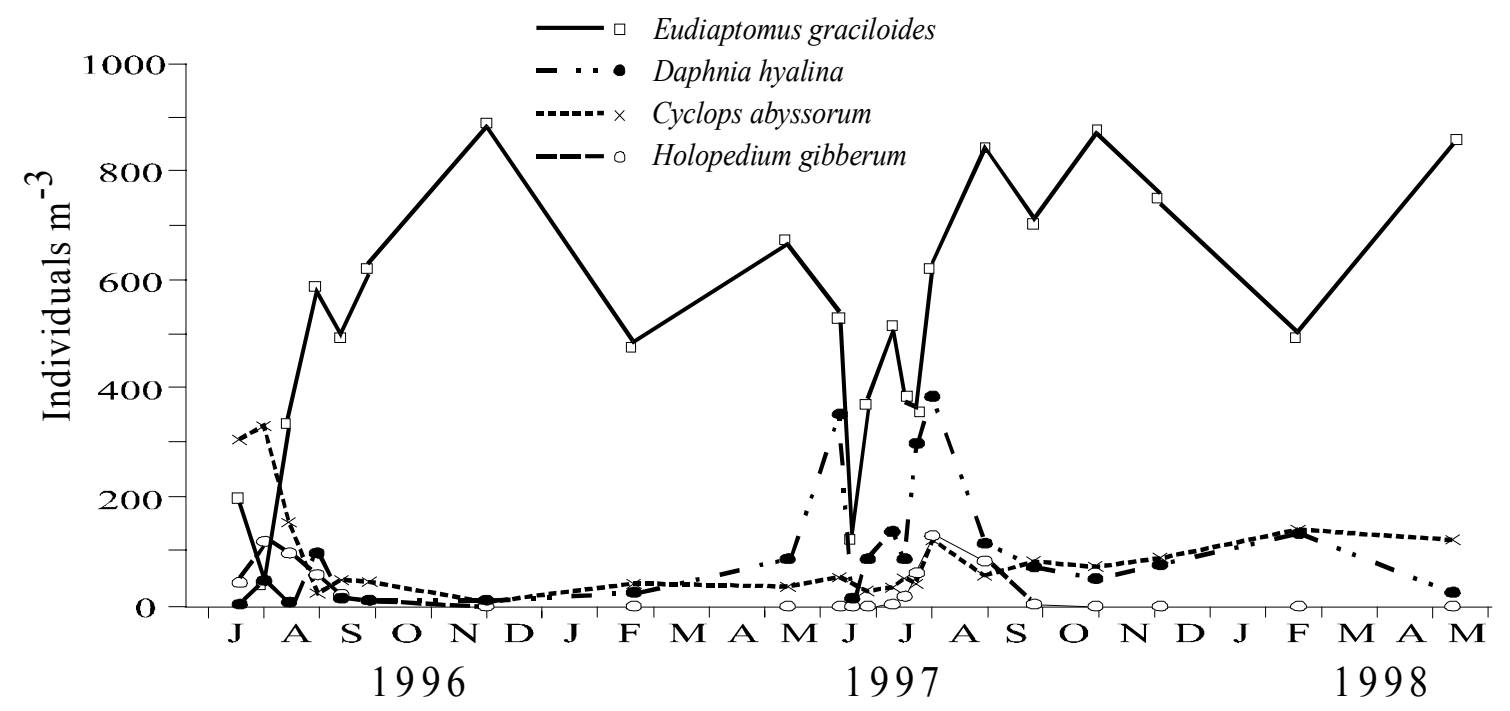

Fig. 7. Seasonal dynamics of the four most dominant crustacean zooplankton species from the pelagic area of Lake Saanajärvi.

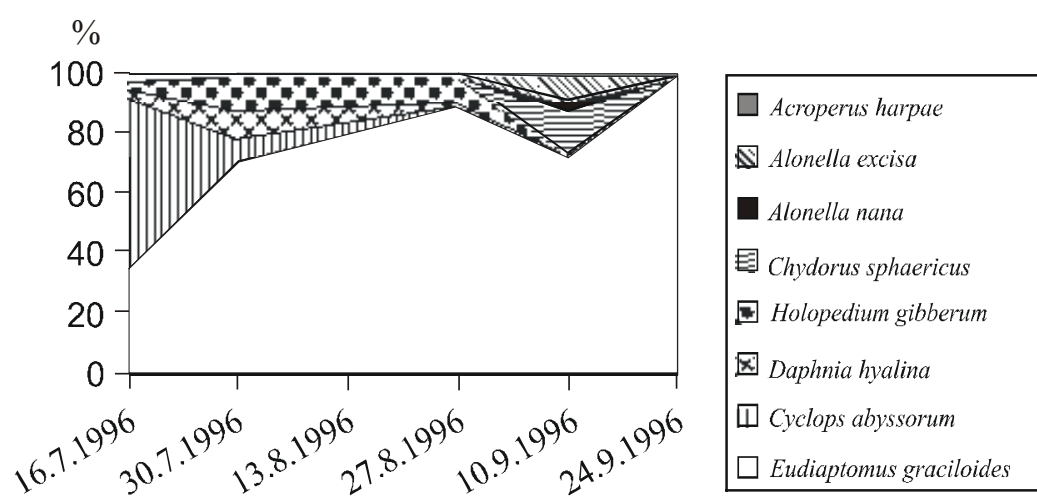

Fig. 8. Seasonal succession of littoral zooplankton.

its number declined to less than 50 individuals $\mathrm{m}^{-3}$ until the end of summer 1997, after which its abundance has remained constant, 120-180 individuals $\mathrm{m}^{-3}$.

Daphnia hyalina and Holopedium gibberum occurred in highest numbers in late summer during the warm water period, which is typical for cladocera (Allan 1977). In summer 1996 the maximum number of $D$. hyalina in the pelagic water column was fairly low, only 100 individuals $\mathrm{m}^{-3}$, whereas in summer 1997 the highest recorded abundance was 400 individuals $\mathrm{cm}^{-3}$. This difference may result from the different sampling interval between the two years. In 1996 sampling was performed twice a month, whereas in 1997 samples were taken every week. Therefore in 1996 some cohort peaks may have been missed. In both 1996 and 1997 H. gibberum appeared in the water column in mid July, when the resting eggs hatched, and disappeared before the end of September. It reached its maximum number, 120-150 individuals $\mathrm{m}^{-3}$, at the end of July.

The littoral zooplankton community consisted mainly of the same species as the pelagic community. This is reasonable since the littoral in Lake Saanajärvi lacks macrophytes, whose presence would provide a suitable habitat for several cladocerans. Despite the lack of higher vegetation 4 species from the family Chydoridae, which is considered to be a group of cladocera strongly associated with macrophytes (Fryer 1985), were found in the littoral. These included phytophilous Alonella nana and Acroperus harpae, which were only found in the littoral, whereas Chydorus sphaericus and Alonella excisa also inhabited the pelagic zone (Fig. 8). This is in accordance with the known habitat preferences of these species (e.g. Whiteside 1974; Hofmann 1987; Korhola 1990).

\subsection{Zooplankton in the traps}

The material in the sediment traps was used to describe the pathways of zooplankton sedimentation from the water column to the bottom of the deepest basin of the lake. The trap material consisted almost solely of Daphnia hyalina remains (Fig. 9), indicating that Copepoda are either almost entirely consumed while alive or they degrade very rapidly after death. The first hypothesis is highly unlikely, since the only planktonic predator in the lake, arctic char (Salvelinus alpinus), preys mainly upon Daphnia (unpubl. data). The trap material demonstrates the over-representation of the Chydoridae and their potential in paleolimnological 

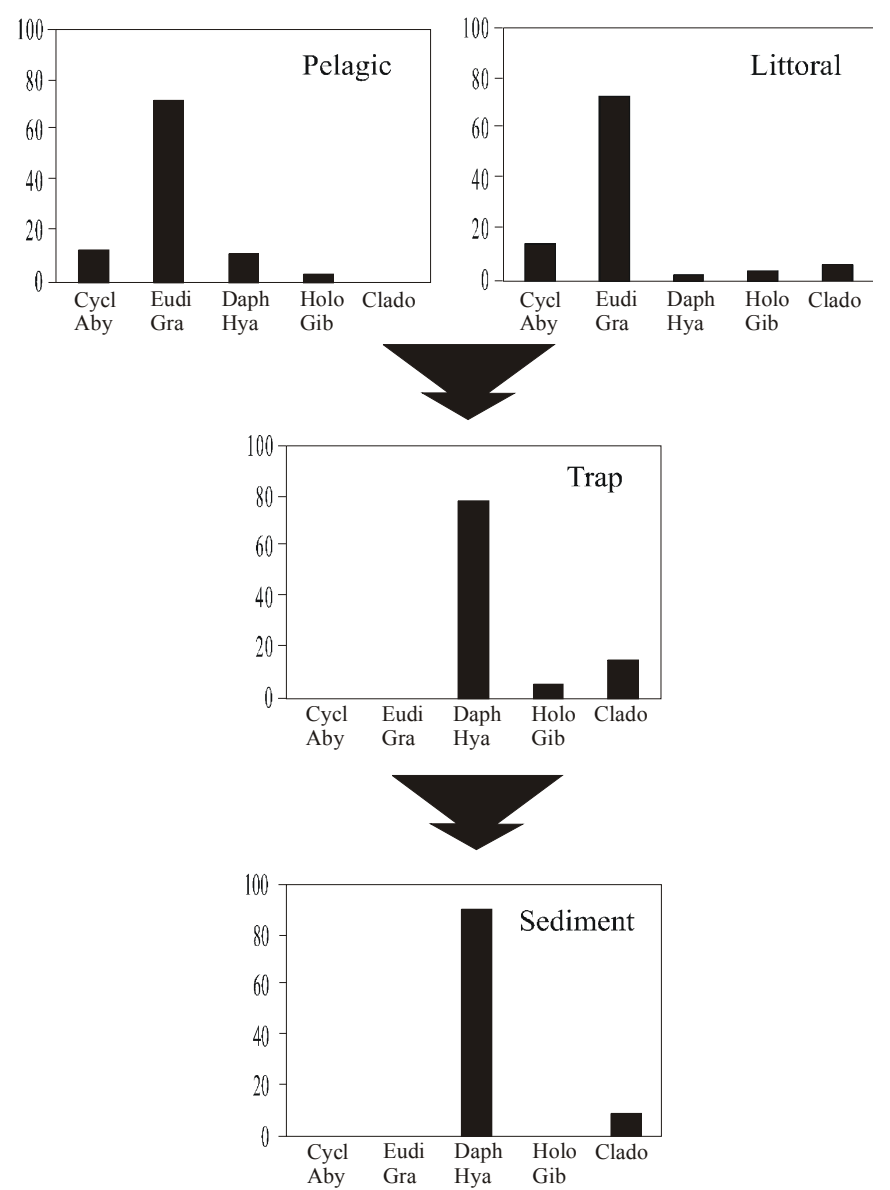

studies, as their proportion of the total cladoceran material in the sediment core is higher from that in the water column.

\subsection{Sediment records of zooplankton}

Cladocera, especially the family Chydoridae, are the only zooplankton group that are usually preserved in the sediments in sufficient quantities (Frey 1960; Whiteside 1969; Korhola 1999). Therefore, only cladoceran remains are considered in the following section. As in the water column, the sediment core of Lake Saanajärvi was also poor in cladocera remains: only 10 taxa were identified and mostly in very low numbers. Throughout the core, the dominant species was Daphnia hyalina, whose proportion always exceeded $50 \%$ of the total number of cladocera remains. Although only a few species of chydorids were caught in the zooplankton during the study period other species of this group were found in the sediment (Fig. 10). This is a common phenomenon, since a lake basin is a natural trap for the matter transported into its catchment as well as organisms living within its waters (e.g. Kerfoot 1974).

The history of each cladoceran species found followed the same general pattern in the sediment. Until the 1930's the cladoceran community seems to have been extremely small, after which there was a clear increase especially in the population of Daphnia hyalina.
Fig. 9. Percentage distribution of zooplankton in the major habitats of Lake Saanajärvi, the transportation and loss or gain of species between different steps of sedimentation. CyclAby $=$ Cyclops abyssorum, EudiGra=Eudiaptomus graciloides, DaphHya=Daphnia hyalina,

HoloGib=Holopedium gibberum, $\mathrm{Clado}=$ Bosmina longispina, Chydorus sphaericus, Alonella nana, Alonella excisa, Alona quadrangularis, Alona affinis, Acroperus harpae, Acroperus elongatus and Eurycercus lamellatus.
The low number of other species makes accurate quantification of these taxa difficult; nevertheless a similar trend to D. hyalina can be detected in Bosmina longispina, Alona affinis, Alona quadrangularis, Acroperus elongatus, Alonella nana, Chydorus sphaericus, Alona excisa and Eurycercus lamellatus, although the shift in these species dates occurred $c a 20$ years later than in the case of D. hyalina.

Cladocerans are considered to provide information on various environmental events and disturbances affecting lake status, such as climatic and trophic state changes (Goulden 1969; Jeppesen et al. 1996; Rautio 1998; Korhola et al. 1999), acidification (Korhola 1992) and water-level fluctuations (Alhonen 1970; SarmajaKorjonen \& Hyvärinen 1999). The relatively recent change in the environmental state of Lake Saanajärvi, which has caused the shift in the cladocera community, cannot be connected with a recovery from acidification or water-level oscillations since there is no evidence of either of these events. In addition, although the 1930's was the warmest decade in the $20^{\text {th }}$ century and the reconstructed temperature values show a temperature increase since the $19^{\text {th }}$ century, the Cladocera are unlikely to have been able to respond to an increase of only a few degrees by becoming more abundant. However, the temperature increase may have been sufficient to create changes in the stratification patterns in the lake and 


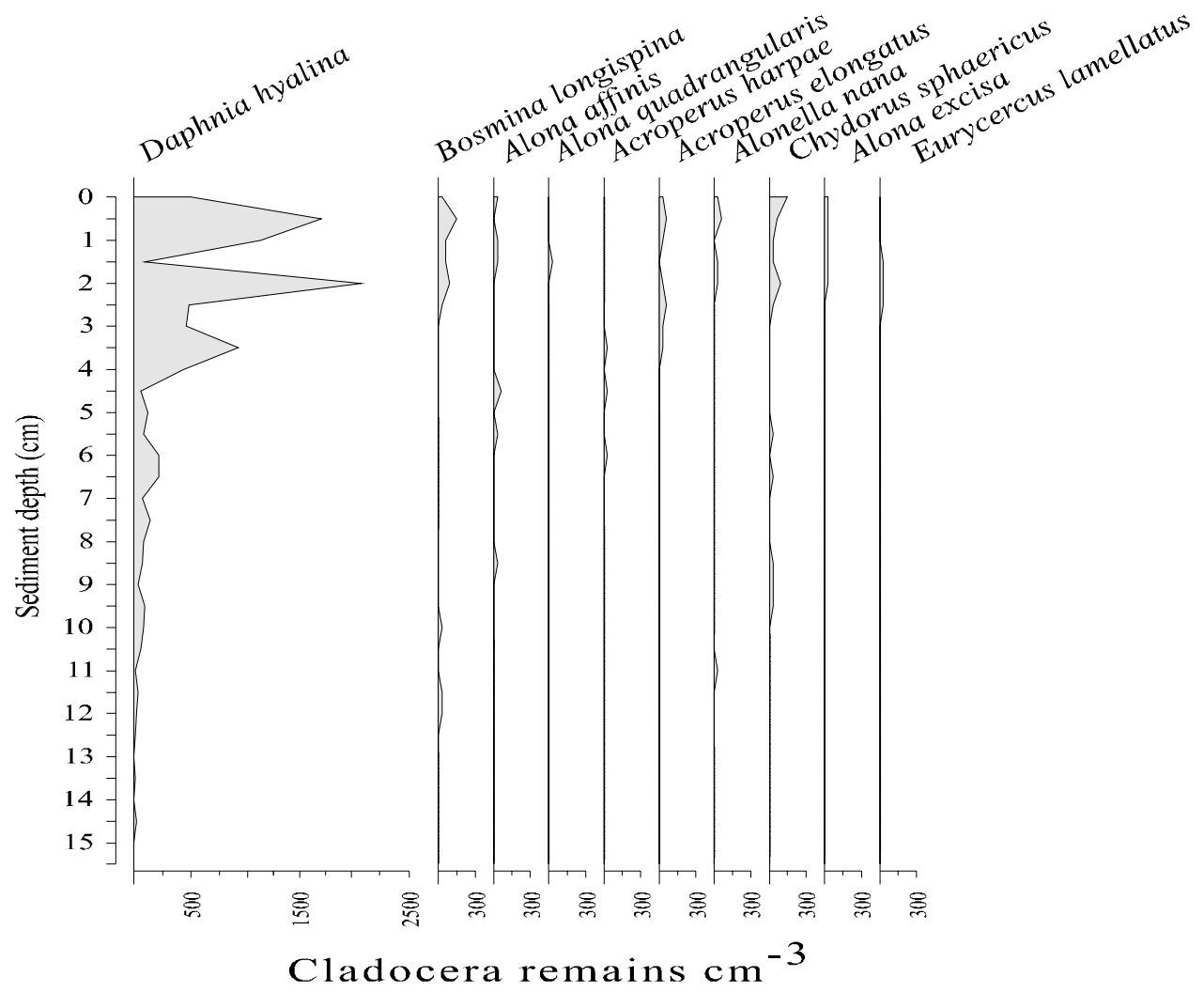

Fig. 10. The distribution of Cladocera remains in the sediment of Lake Saanajärvi. thereby to effect the composition and production of the phytoplankton community (Korhola et al. 2000), which, in turn may have caused an increase in cladoceran production via trophic cascades.

\subsection{Representation of diatom and zooplankton communities in the sediment core}

Sediment focusing is a process whereby water turbulence moves sediment material, including remains of organisms, from shallower to deeper zones of lakes (Blais \& Kalff 1995). Sediment distribution in a lake is a function of many external factors, such as hydrological flow, topography, shelter and climate, which influence physical limnological processes (e.g. thermocline depth, time of turnover, wave action). On the basis of the operation of these processes a lake basin can be divided into three different zones; an erosion zone, a transportation zone and an accumulation zone (Håkansson \& Jansson 1983). The accumulation zone is least affected by wind-driven turbulence, allowing accumulation of fine-grained sediments and resuspended material. In paleolimnology, the studies are based on the assumption that a single, centrally located core is representative of all the biological material derived from different microhabitats in the lake. Moreover, it is sometimes assumed that allochthonous inputs from the catchment or from reworked sediments are minimal and constant through time. Nevertheless, many studies show that accumulations of remains and the representation of different communities of organisms may be nonuniform (e.g. Meriläinen 1971; Battarbee 1978; Anderson 1989, 1990, 1994)

Taphonomy is a study of all post-mortem processes that modify the remains of organisms to produce fossils (Cameron 1995). An important field of taphonomy deals with the description of whole biological communities on the basis of fossil assemblages. Major factors that affect the composition of species assemblages in deep-water sediments are temporal changes in abundance of species in the contemporary communities; spatial distribution and areal coverage of the communities; production rates of the species; and transport-sedimentation processes in the lake (DeNicola 1986).

One approach to assessing species representativity in sediment core material is to compare old species records with known sediment samples (Battarbee 1979). However, this method may cause problems with taxonomic consistency. An alternative approach is to compare to composition of contemporary communities with the composition of surface sediment assemblages. DeNicola (1986) and Jones \& Flower (1986), among others, have successfully used this approach. As Lake Saanajärvi has undergone a distinct floristic change during its history we chose only the topmost $1 \mathrm{~cm}$ of the sediment core to represent 'recent' communities. The uppermost $1 \mathrm{~cm}$ represents approximately the last 30 years and contains two (Cladocera) to five (diatom) pooled subsamples.

Diatom representation in sediment core material was estimated by studying different recent community components. All trap samples together were used as a surro- 
gate for plankton habitat, whereas, according to DCA, transect samples formed three different groups; epilithon assemblages, shallow surface sediment assemblages (7-16 m) and deep surface sediment assemblages (21-24 m). The epiphytic habitat is absent because macrophytes were not present in the littoral zone.

Table 3 shows all five diatom components (plankton, epilithon, shallow \& deep surface sediment and sediment core assemblage) with the criterion of occurrence of over $1 \%$ in at least one component. Achnanthes species, Brachysira vitrea and Denticula tenuis dominated the epilithon. Achnanthes minutissima alone comprised almost $50 \%$ of the epilithon habitat. It is known as an epilithic and epiphytic taxon which can be present anywhere in the lake (Round et al. 1990) and therefore is more easily transported. Our data show clearly that $A$. minutissima was found in each microhabitat in Lake Saanajärvi. Although it appeared in its highest numbers in the epilithon, it was present at approximately $10 \%$ in all other habitats. Most of the other Achnanthes species were also found mainly in the epilithon. However, $A$. levanderi was exceptionally abundant $(6.5 \%)$ in the deep surface sediment (21-24 m), and A. suchlandtii occurred in all other habitats except the epilithon, varying from $1 \%$ to $3 \%$.

As expected, all the planktonic diatoms, such as $C y$ clotella species and Thalassiosira pseudonana, occurred only in very small numbers in the epilithon but increased gradually in numbers when moving towards plankton and the deep-water sediments. Thalassiosira pseudonana was present in the water column at $6.8 \%$ and was present in the deep surface sediment assemblage material at $3.0 \%$. Aulacoseira subarctica has an abundance of $6.4 \%$ in the water column, but was absent in other habitats. Cyclotella comensis and C. glomerata, which were the dominant taxa $(20.0 \%$ and $21.3 \%$, respectively) in sediment core material, were also expected to be abundant in water column. $C$. comensis had the highest abundance $(23.8 \%)$ in the water column, but C. glomerata was present in the water column only at $1.2 \%$. As discussed above, it seems that $C$. glomerata was absent in the water column during the study period.

Shallow and deep surface sediment assemblages were dominated by planktonic Cyclotella species and Achnanthes minutissima, which indicates the strong sedimentation effect of diatoms living in the water column. Unattached or loosely attached benthic Fragilaria species ( $F$. brevistriata, $F$. pinnata, $F$. pseudoconstruens) and Navicula species (N. schmassmannii and $N$. seminulum) had their maximum abundance in the surface sediment habitats. These species were present only in low numbers in the epilithon and in the plankton.

When comparing the species composition in different lake habitats to the species assemblage in the sediment core, it is evident that the sediment core taken from the deepest point of Lake Saanajärvi is very representative of the entire diatom community in the lake.
$61.7 \%$ of the taxa inhabiting the epilithon were present in topmost part of the sediment core, while plankton community was represented by $64.1 \%$ proportions in the sediment core; the sediment core assemblage thus slightly underestimates epilithon and plankton habitats. $76.1 \%$ of the taxa from the shallow surface sediments were the same as in the sediment core assemblage, whereas the surface sediment samples from the deeper area of the lake contained $83.6 \%$ of the species found in the sediment core.

Instead of studying only data on the presence or absence of species, the similarity and thus the representatives of different assemblages can be examined more sensitively using a methodology specifically designed to determine similarities by taking the whole community structure into account. The method applied here was the squared Chi-square distance dissimilarity (SCD) method. The comparison of planktonic assemblage found in the trap material to the planktonic assemblage into the sediment core yielded a dissimilarity value of 0.51 , whilst the corresponding value for the periphytic assemblages from the transect and the core was 0.68 . These dissimilarity values can now be compared to the critical values of SCD determined by Flower et al. (1997) on the basis of the modern diatom data from ca. 200 lakes in Britain, Ireland, Sweden and Norway. According to their definition, the thresholds of 0.57 and 0.65 can be used to indicate 'very good' and 'good' analogies, respectively (Flower et al. 1997). Therefore it appears that a very good analogy exists in Lake Saanajärvi between planktonic assemblages from trap and sediment core material, whereas the similarity of nonplanktonic assemblages between the transect and the sediment core is only moderately good. We may conclude that a single surface sediment sample taken from the middle of Lake Saanajärvi reflects the overall diatom community representing different microhabitats in the lake rather well but is better for the plankton than non-plankton.

In Lake Saanajärvi, investigations for one-season in the littoral, for two-years in the pelagic zone as well as the collection of sedimenting material in traps and the deepest basin show that sedimentation processes and species representation in the sediments vary among the different zooplankton species. As Lake Saanajärvi is a typical subarctic lake, the living zooplankton community is dominated by few calanoid copepods, whereas due to the lack of littoral macrophytes only pelagic cladocerans, such as Daphnia, Bosmina and Holopedium, occur. In Lake Saanajärvi Eudiaptomus graciloides was the clear dominant species both in the pelagic and in the littoral accounting for over $70 \%$ of the total species abundance. The second most abundant species, Cyclops abyssorum, was responsible for $12 \%$ and $15 \%$ in the pelagic and littoral, respectively. Daphnia hyalina accounted for nearly $12 \%$ of the community in the pelagic but for less than $3 \%$ in the littoral, whereas the propor- 
Tab. 3. Distribution of the most common diatoms in different habitats in Lake Saanajärvi and in the topmost section of core SAAN3. All diatom proportions are expessed as percentages, and the most common taxa are selected with a criterion of occurrence of over $1 \%$ in at least one of the components.

\begin{tabular}{|c|c|c|c|c|c|}
\hline Taxon & Epilithon habitat & Plankton habitat & $\begin{array}{c}\text { Shallow surface } \\
\text { sediment }(7-16 \mathrm{~m})\end{array}$ & $\begin{array}{c}\text { Deep surface } \\
\text { sediment }(21-24 m)\end{array}$ & $\begin{array}{l}\text { Sediment core } \\
\text { assemblage }\end{array}$ \\
\hline Achnanthes carissima & 0.7 & 0.1 & 0.8 & 1.1 & 0.3 \\
\hline Achnanthes curtissima & - & 0.9 & 1.9 & 1.3 & 1.1 \\
\hline Achnanthes didyma & 0.1 & 0.3 & 1.0 & 0.5 & 1.0 \\
\hline Achnanthes kreigerii & 1.7 & 0.3 & 0.2 & 0.3 & - \\
\hline Achnanthes laterostata & 0.5 & 0.4 & 1.0 & 0.4 & 0.5 \\
\hline Achnanthes levanderi & 0.6 & 1.2 & 3.9 & 6.5 & 2.2 \\
\hline Achnanthes minutissima & 49.5 & 8.7 & 11.1 & 4.9 & 9.8 \\
\hline Achnanthes nodosa & 1.3 & 0.4 & 0.2 & 0.1 & 0.6 \\
\hline Achnanthes pusilla & 3.3 & 1.2 & 1.4 & 2.5 & 1.1 \\
\hline Achnanthes subatomoides & 0.9 & - & 0.3 & 0.1 & 1.0 \\
\hline Achnanthes suchtlandtii & 0.5 & 1.2 & 2.9 & 1.1 & 2.0 \\
\hline Achnanthes sp I & 0.5 & 0.2 & 1.7 & 1.6 & 1.8 \\
\hline Amphora fogediana & 0.6 & - & 1.0 & 0.4 & 0.1 \\
\hline Aulacoseira distans var. nivalis & - & - & 1.4 & 0.1 & - \\
\hline Aulacoseira subarctica & - & 6.4 & 0.1 & 0.1 & 0.3 \\
\hline Brachysira vitrea & 5.2 & 1.1 & 0.7 & 1.4 & 1.2 \\
\hline Cyclotella comensis & 1.7 & 23.8 & 15.2 & 14.1 & 20.0 \\
\hline Cyclotella glomerata & 0.2 & 1.2 & 5.2 & 21.5 & 21.3 \\
\hline Cyclotella rossii & 1.3 & 15.0 & 8.9 & 8.0 & 7.0 \\
\hline Cyclotella schumannii & 0.1 & 0.2 & 0.3 & 1.4 & 0.4 \\
\hline Cymbella microcephala & 2.3 & 0.5 & 0.2 & 0.8 & 0.4 \\
\hline Cocconeis placentula & 2.1 & - & 0.3 & - & 0.2 \\
\hline Cymbella silesiaca & 0.5 & 1.7 & 0.8 & 0.5 & 0.5 \\
\hline Denticula tenuis & 10.3 & 1.8 & 0.3 & 1.0 & 1.0 \\
\hline Eunotia $\mathrm{spp}$ & 1.1 & 0.3 & - & 0.1 & - \\
\hline Fragilaria brevistriata & 0.4 & 1.8 & 4.6 & 2.4 & 4.7 \\
\hline Fragilaria pinnata & 0.1 & 0.6 & 2.4 & 12.0 & 0.9 \\
\hline Fragilaria pseudoconstruens & 0.1 & 1.9 & 4.2 & 4.8 & 2.1 \\
\hline Gomphonema sp. & 2.4 & 0.4 & 0.3 & 0.3 & 0.1 \\
\hline Navicula minima v. minima & 0.1 & - & 1.9 & 1.0 & - \\
\hline Navicula modica & - & 0.2 & 1.4 & 0.1 & 0.1 \\
\hline Navicula perpusilla & - & - & 1.2 & - & - \\
\hline Navicula schmassmannii & - & 1.4 & 1.9 & 2.6 & 2.1 \\
\hline Navicula seminulum & 0.1 & 1.0 & 0.8 & 2.0 & 1.0 \\
\hline Navicula seminulum var. intermedia & 0.1 & - & 1.0 & 0.4 & 0.7 \\
\hline Nitzschia fonticola & - & 0.9 & 1.9 & 1.8 & - \\
\hline Nitzschia dissipata & 0.4 & 1.2 & 0.8 & 0.3 & 1.1 \\
\hline Nitzschia perminuta & 2.4 & 0.8 & 0.7 & 0.8 & 0.3 \\
\hline Pinnularia balfouriana & 0.2 & 0.8 & 1.5 & 1.0 & 1.4 \\
\hline Thalassiosira pseudonana & - & 6.8 & 1.2 & 3.0 & 2.5 \\
\hline
\end{tabular}

tion of Bosmina and chydorids increased from nearly zero in the pelagic to $6.5 \%$ in the littoral (Fig. 9).

Zooplankton disarticulate at death into a variety of parts, such as carapaces, claws, postabdomens, mandibles, segments of antenna (only copepoda) and headshields (only cladocera), which are identifiable to varying degrees. The chitinous skeletal structures of cladocera preserve better than soft-bodied copepoda, resulting in the shift from copepod-dominated water column material to Cladocera-dominated sediment trap and fossil material, i.e. in the sediment copepods are no longer detectable. Moreover, littoral chydorid Cladocera are generally better preserved than planktonic Cladocera (e.g. Hofmann 1987; Hann 1989) which was also the case in our study. The proportion of chydorids increased from the assemblages found in the open water in comparison to those found in the sediments (Fig. 9). Planktonic Holopedium gibberum was detectable by its postabdominal parts in the sediment trap material but was no longer present in the sediment, whereas the proportion of chydorids to the rest of the zooplankton community increased from the pelagic water column to the sediment. The fossil record of zooplankton is, thus, strongly variable within the different taxonomic groups, both in terms of the degree of taxonomic resolution that can be achieved and the faithfulness of the fossil assemblage to the source community (Anderson \& Battarbee 1992). 


\section{CONCLUSIONS}

We studied 1) the spatial distribution of diatoms and zooplankton in the major habitats of Lake Saanajärvi, 2) the transportation and loss or gain of species between different stages of sedimentation, and 3) variability in species composition and with time in the sediments.

As planktonic species assemblages in the lake were typical of subarctic oligotrophic lakes with a bare rock littoral, pelagic diatom species such as Cyclotella and Thalassiosira, copepods, and Daphnia -zooplankton dominated the planktonic community together with chrysophytes, which were only considered at the level of algal class. The comparison of the present plankton community in the lake with the species assemblage in the sediment surface revealed that only a small, selected fraction of the contemporary biota is preserved in the sediments, as is most clearly indicated by zooplankton (Fig. 9). Therefore, in studies of microfossils in lake sediments, caution should be excercised when drawing conclusions based on the observation of single, small samples, extracted from a very large population by comparison. On the other hand, some taxonomic groups, such as the diatoms, are preserved so well in the sediment that the deepest basin can be considered a better collector of these taxa than years of extensive water column sampling or sampling non-planktonic habitats.

\section{ACKNOWLEDGMENTS}

The study was funded by the European Community Environment and Climate Programme (MOLAR Proj??ect; Contract No. ENV4-CT95-0007 and Academy of Finland (Contract No. 7383 and 40868). We thank the Finnish Forest Institute, Kilpisjärvi branch, for the help in the field and Kilpisjärvi Biological Station for laboratory facilities.

\section{REFERENCES}

Alhonen, P. 1970. On the significance of the planktonic/littoral ratios in the cladoceran stratigraphy of lake sediments. Soc. Sci. Fenn. Comm. Biol., 35: 1-9.

Allan, J.D. 1977. An analyses of seasonal dynamics of a mixed population of Daphnia and the associated cladoceran community. Freshwat. Biol., 7: 505-512.

Anderson, N.J. 1989. A whole-basin diatom accumulation rate for a small eutrophic lake in Northern Ireland and its palaeoecological implications. J. Ecol., 77: 926-946.

Anderson, N.J. 1990. Variability of sediment diatom assemblages in an upland, wind-stressed lake (Loch Fleet, Galloway, S.W. scotland). J.Paleolimnol., 4: 43-59.

Anderson, N.J. 1994. Spatial heterogeneity of diatom stratigraphy in varved and non-varved sediments of a small, boreal-forest lake. Aquatic Sciences, 56: 40-58

Anderson, N.J. \& R.W. Battarbee. 1992. Aquatic community persistence and variability: a paleolimnological perspective. In: Giller et al. (Eds), Aquatic Ecology: scale, pattern and process. The $34^{\text {th }}$ Symposium of the British Ecological Society, University College, Cork 1992: 233-259.

Anderson, N.J. \& I. Renberg. 1992. A palaeolimnological assessment of diatom production responses to lake acidification. Environmental Pollution, 78: 113-119.
Anderson, N.J., P. Blomqvist \& I. Renberg. 1997. An experimental and palaeoecological study of algae responses to lake acidification and liming in three central Swedish lakes. Eur. J. Phycol., 32: 35-48.

Anderson N.J., B.V. Odgaard, U. Segerström \& I. Renberg. 1996. Climate-lake interactions recorded in varved sediments from a Swedish borel forest lake. Global Change Biology, 2: 399-405.

Battarbee, R.W. 1978. Biostratigraphical evidence for variations in the recent pattern of sediment accumulation in Loch Neagh, Norther Ireland. Verh. int. Ver. Limnol., 20: 625-629.

Battarbee, R.W. 1979. Early algological records: help or hindrance to palaeolimnology? Nova Hedwigia, 64: 379-393.

Battarbee, R.W. 1984. Diatom analysis and the acidification of lakes. Phil. Trans. Soc. Lond., B 305: 451-477.

Blais, J.M., \& J. Kalff. 1995. The influence of lake morphometry on sediment focusing. Limnol. Oceanogr., 40: 582-588.

Bennion, H. 1995. Surface-sediment diatom assemblages in shallow, artificial, enriched ponds, and implications for reconstructing trophic status. Diatom Research, 10: 1-19.

Cameron, N.G. 1995. The representation of diatom communities by fossil assemblages in a small acid lake. J. Paleolimnol., 14: 185-223.

Capin, F.S. III \& Ch. Körner (Eds). 1995. Arctic and Alpine Biodiversity. Ecological Studies 113. Springer: 332 pp.

Carter, J.C.H., M.J Dadswell, J.C. Rolf \& W.G. Sprules. 1980. Distribution and zoogeography of planktonic crustaceans and dipterans in glaciated eastern North America. Can. J. Zool., 58: 1355-1387.

Charles, D.C., D.R Whitehead, D. Anderson, R. Bienert, K. Camburn, R. Cook, T. Crisman, R.B. Davis, B. Fry, R.A. Hites, J.S. Kahl, J. Kingston, R. Jr. Kreis, M.J. Mitchell, S.A. Norton, L. Roll, J.P. Smol, P.R. Sweets, A. Uutala, J. White, M. Whiting \& R. Wise. 1986. The PIRLA project (Paleoecological Investigation of Recent Lake Acidification): preliminary results for the Adirondacks, New England, N. Great Lakes States, and N. Florida. Water, Air and Soil Pollution, 30: 355-365.

Cronberg, G. 1986. Chrysophycean cyst and scales in lake sediments: a review. In: J. Kristiansen \& R.A. Andersen (Eds), Chrysophytes: Aspects and Problems. Cambridge University Press, Cambridge: 281-315.

DeNicola, D.M. 1986. The representation of living diatom communities in deep-water sedimentary diatom assemblages in two Maine (U.S.A.) lakes. In: Smol, J.P., R.W. Batterbee, R.B. Davis \& J. Meriläinen (Eds). Diatoms and Lake Acidity. Dr W. Junk Publisher, Dordrecht: 73-85 pp.

Douglas, S.V. M. \& J.P. Smol. 1995. Paleolimnological significance of observed distribution patterns of chrysophyte cysts in arctic pond environments. J. Paleolimnol., 13: 7983.

Douglas, S.V.M., J.P. Smol \& W. Blake Jr. 1994. Marked post-18th century environmental change in high-arctic ecosystems. Science, 266: 416-419.

Duff, K.E., B.A. Zeeb \& J.P. Smol. 1995. Atlas of Chrysophycean cysts. Kluwer Academic Publishers. The Netherlands.

Elgmork, K. \& J.A. Eie. 1989: Two- and three-year life cycles in the planktonic copepod Cyclops scutifer in two high mountain lakes. Holoarctic Ecology, 12: 60-69.

Facher, E. \& R. Schmidt. 1996. A siliceous chrysophycean cyst-based $\mathrm{pH}$ transfer function for Central European lakes. J. Paleolimnol., 16: 275-321.

Flower, R.J., S. Juggins \& R.W. Batterbee. 1997. Matching diatom assemblages in lake sediment cores and modern surface sediment samples: the implications for lake conservation and restoration with special reference to acidified systems. Hydrobiologia, 344: 27-40. 
Flössner, D. 1972. Kiemen- und Blattfüsser, Branchiopoda, Fischläuse, Branchiura. Tierwelt Deutsch, 60: 1-499.

Forsström, L. 2000. Seasonal succession of phytoplankton in Lake Saanajärvi, northern Finland. Master's thesis. In Finnish.

Frey, D.G. 1959: The taxonomic and phylogenic significance of the head pores of the Chydoridae (Cladocera). Int. Rev. ges. Hydrobiol., 44: 27-50.

Frey, D.G. 1960: The ecological significance of cladoceran remains in lake sediments. Ecology, 41: 684-699.

Fryer, G. 1985. Crustacean diversity in relation to the size of water bodies: some facts and problems. Freshwat. Biol., 15: $347-361$.

Gaedke, U., R. Adrian, H. Bucka, L. Havel, J. Keskitalo, N. Mineeva \& I. Winfield. 1998. Detecting and predicting the responses of lakes to global climate change (Working group topic 2). In: D.G. George et al. (Eds), Management of lakes and reservoirs during Global Climate Change. Kluwer Academic Publishers, Netherlands.

Gajewski, K., P.B. Hamilton \& R. McNeely. 1997. A high resolution proxy-climate record from an arctic lake with annually laminated sediments on Devon Island, Nunavut, Canada. J. Paleolimnol., 17: 215-225.

George, D.G. \& A.H. Taylor. 1995. UK lake plankton and the Gulf Stream. Nature, 378: 139.

Goulden, C.E. 1969: Interpretative studies of cladoceran microfossils in lake sediments. Mitt. Internat. Verein. Limnol., 17: 43-55.

Hann, B.J. 1989. Cladocera. Methods in Quaternary Ecology. Geoscience Canada, 16

Hansson, L.-A., M. Lindell \& L.J. Tranvik. 1993. Biomass distribution among trophic levels in lakes lacking vertebrate predators. Oikos, 66: 101-106.

Hartley, B. 1986. A Check-list of the freshwater, brackish and marine diatoms of the British Isles and adjoining coastal waters. Journal of the British Marine Biological Association, 66: 531-610.

Haworth, E.Y. 1980. Comparison of continuous phytoplankton records with diatom stratigraphy in the recent sediments of Blelhan Tarn, English Lake District. Limnol. Oceanogr., 25: 1093-1103.

Hill, M.O. \& H.G. Gauch 1980. Detrended correspondence analysis: an improved ordination technique. Vegetatio, 42 47-58.

Hofmann, W. 1987. Cladocera in space and time: analysis of lake sediments. Hydrobiologia, 145: 315-321.

Håkanson, L. \& M. Jansson. 1983. Principles of the lake sedimentology. Berlin, Springer-Verlag.

Jeppesen, E., E.A Madsen, J.P. Jensen \& N.J. Anderson. 1996. Reconstructing the past density of planktivorous fish and trophic structure from sedimentary zooplankton fossils: a surface sediemnt calibration data set from shallow lakes. Freshwat. Biol., 36: 115-127.

Jones, P.D., K.R. Briffa, T.P. Barnett \& S.F.B. Tett. 1998 High-resolution palaeoclimatic records for the last millennium: interpretation, intergration and comparison with General Circulation Model control-run temperatures. The Holocene, 8: 455-471.

Jones, V.J. \& R.J. Flower. 1986. Spatial and temporal variability in periphytic diatom communities: palaeoecological significance in an acid lake. In: J.P. Smol, R.W. Battarbee, R.B. Davis \& J. Meriläinen (Eds), Diatoms and lake acidity. Junk, Dordrecht: 73-85.

Kalff, J. \& H.E. Welch. 1974. Phytoplankton production in Char Lake, a natural polar lake, and in Meretta Lake, a polluted polar lake, Cornwallis Island, Northwest Territories. J. Fish. Res. Board Can., 31: 621-636.

Kalff, J., H.J. Kling, S.H. Holmgren \& H.E. Welch. 1975. Phytoplankton, phytoplankton growth and biomass cycles in an unpolluted and in a polluted polar lake. Verh. int. Ver. Limnol., 19: 487-495.
Kerfoot, W.C. 1974. Net accumulation rates and the theory of cladoceran communities. Ecology, 55: 51-61.

Korhola, A. 1992: The Early Holocene hydrosere in a small acid hill-top basin studied using crustacean sedimentary remains. J. Paleolimnol., 7: 1-22.

Korhola, A. 1999. Distribution patterns of Cladocera in subarctic Fennoscandian lakes and their potential in environmental reconstruction. Ecography, 22: 357-373.

Korhola, A., S. Sorvari, M. Rautio, P.G. Appleby, J.A. Dearing, N. Rose, A. Lami \& N.G. Cameron. (2000). A Multiproxy analysis of climate impacts on recent ontogeny of subarctic Lake Saanajärvi in Finnish Lapland. J. Paleolimnol.: (in press).

Lotter, A., H.J.B. Birks, W. Hofmann \& A. Marchetto. 1997. Modern diatom, cladocera, chironomid, and Chrysophyte cyst assemblages as quantitative indicators for the reconstruction of past environmental conditions in the Alps. I. Climate. J. Paleolimnol., 18: 395-420.

Lotter, A., H.J.B. Birks, W. Hofmann \& A. Marchetto. 1998. Modern diatom, cladocera, chironomid, and Chrysophyte cyst assemblages as quantitative indicators for the reconstruction of past environmental conditions in the Alps. II. Nutrients. J. Paleolimnol., 19: 443-463.

Meriläinen, J. 1971. The recent sedimentation of diatom frustules in four meromictic lakes. Ann. Bot. Fenn., 8: 160176.

Moberg, A. \& H. Alexandersson 1997. Homogenization of Swedish temperature data. Part II: homogenized gridded air temperature compared with a subset of global gridded air temperature since 1861. Int. J. Climat., 17: 35-54.

Moore, J.W. 1979. Factors influencing the diversity, species composition and abundance of phytoplankton in twentyone arctic and subarctic lakes. Int. Revue ges. Hydrobiol., 64: 485-499.

Nauwerck, A. 1994. A survey on water chemistry and plankton in high mountain lakes in northern Swedish Lapland. Hydrobiologia, 274: 91-100.

Overpeck, J.T., T. Webb III \& I.C. Prentice. 1985. Quantitative interpretation of fossil pollen spectra: dissimilarity coefficients and method of modern analogues. Quaternary Res., 23: 87-108.

Overpeck, J, K. Hughen, D. Hardy, R. Bradley, R. Case, M. Douglas, B. Finney, K. Gajewski, G. Jacoby, A. Jennings, S. Lamoureux, A. Lasca, G. MacDonald, J. Moore, M. Retelle, S. Smith, A. Wolfe \& G. Zielinski. 1997. Arctic environmental change of the last four centuries. Science, 278: 1251-1256.

Prentice, I.C. 1980. Multidimensional scaling as a research tool in quarternary palynology: a review of theory and methods. Rev. Palaeobot. Palynol., 31: 71-104.

Rautio, M. 1998. Community structure of crustacean zooplankton in subarctic ponds - effects of altitude and physical heterogeneity. Ecography, 21, 327-335.

Reynolds, C.S. 1998a. Linkages between atmospheric weather and the dynamics of limnetic phytoplankton. In: D.G. George et al. (Eds), Management of lakes and reservoirs during global climate change. Kluwer Academic Publishers, Netherlands.

Reynolds, C.S. 1998b. What factors influence the species composition of phytoplankton in lakes of different trophic status? Hydrobiologia, 3699/379: 11-26.

Round, F.E., M. Crawford \& D.G. Mann. 1990. Diatoms. Cambridge University Press, Cambridge: $747 \mathrm{pp}$.

Rylov, V.M. (Ed.). 1963. Fauna of U.S.S.R.: Freshwater $C y$ clopoida. Israel Program for Scientific Translations: 314 pp.

Sarmaja-Korjonen, K. \& H. Hyvärinen. 1999. Cladoceran and diaton stratigraphy of calcerous lake sediments from $\mathrm{Ku}$ usamo, NE Finland. Indications of Holocene lake-level changes. Fennia, 177: 55-70. 
Selin, P. \& L. Hakkari. 1982. The diversity, biomass and production of zooplankton in lake Inarijärvi. Hydrobiologia, 86: $55-59$

Seppä, H. \& J. Weckström. (2000). Holocene vegetation and limnological changes in the Fennoscandian tree-line area as documented by pollen and diatom records from Lake Tsuolbmajavri. Finland Écoscience: (in press).

Smol, J.P. 1985. The ratio of diatom frustules to chrysophycean statospores: a useful paleolimnological index: $\mathrm{Hy}$ drobiologia, 123: 199-208.

Sommer, U. 1983. Light, stratification and zooplankton as controlling factors for the spring development of phytoplankton in Lake Constance. Schweiz. Z. Hydrol., 45: $394-$ 404.

Sorvari, S. \& A. Korhola. 1998. Recent diatom assemblage changes in subarctic Lake Saanajärvi, NW Finnish Lapland, and their paleoenvironmental implications. J. Paleolimnol., 20: 205-215.

Sorvari. S., M. Rautio \& A. Korhola. 2000. Seasonal dynamics of subarctic Lake Saanajärvi in Finnish Lapland. Verh. int. Ver. Limnol., 27: 507-512.

ter Braak, C.J.F. \& I.C. Prentice. 1988. A theory of gradient analysis. Advances in Ecological Research, 18: 271-317.

ter Braak, C.J.F. 1988. CANOCO- a FORTRAN program for canonical community ordination by [partial] [detrended] [canonical] correspondence analysis, principal components analysis and redundance analysis (version 2.10). Agricultural Mathematics Group Technical Report LWA88-02. Wageningen: Agricultural Mathematics Group: 95 pp. ter Braak, C.J.F. 1990. Updated notes: CANOCO version 3.10. Wageningen : Agricultural Mathematics Group: $35 \mathrm{pp}$.

Thompson, R. \& R.M. Clark. 1993. Quantitative marine sediment core matching using a modified sequence-slotting algorithm. In: E. A. Hailwood \& R. B. Kidd (Eds), High Resolution Stratigraphy. J. Geol. Soc. Lond. Spec. Publ. No. 70: 39-49.

Utermöhl, H. 1958: Zur Vervollkommnung der quantitativen Phytoplankton-Methodik. Mitt. int. Ver. Limnol., 9: 1-38.

Weckström J., A. Korhola, T. Blom. 1997. Diatoms as quantitative indicators of $\mathrm{pH}$ and water temperature in subarctic Fennoscandian lakes. Hybrobiologia, 347: 171-184.

Whiteside, M.C. 1969. Chydorid (Cladocera) remains in surficial sediments of Danish lakes and their significance to paleolimnological interpretations. Mitt. int. Ver. Limnol., 17: 193-201.

Whiteside, M.C. 1974. Chydorid (Cladocera) ecology: seasonal patterns and abundance of populations in Elk Lake, Minnesota. Ecology, 55: 538-550.

Wilkinson, A.N., B.A. Zeeb, J.P. Smol \& M.S.V. Douglas. 1997. Chrysophyte stomatocyst assemblages associated with periphytic, high arctic pond environments. Nordic Journal of Botany, 17: 95-112.

Wilkinson, A.N., R.I. Hall, J.P. Smol. 1999. Chrysophyte cyst as palaelimnological indicators of environmental change due to to cottage development and acidic deposition in the Muskoka-Hliburton region, Ontario, Canada. J. Paleolimnol., 22: 17-39.

Zeeb, B.A. \& J.P. Smol. 1993. Chrysophycean cyst flora from Elk Lake, Clearwater County, Minnesota. Can. J. Bot., 71: 737-756. 